\title{
Hispanic Worker Dies In Tractor Rollover
}

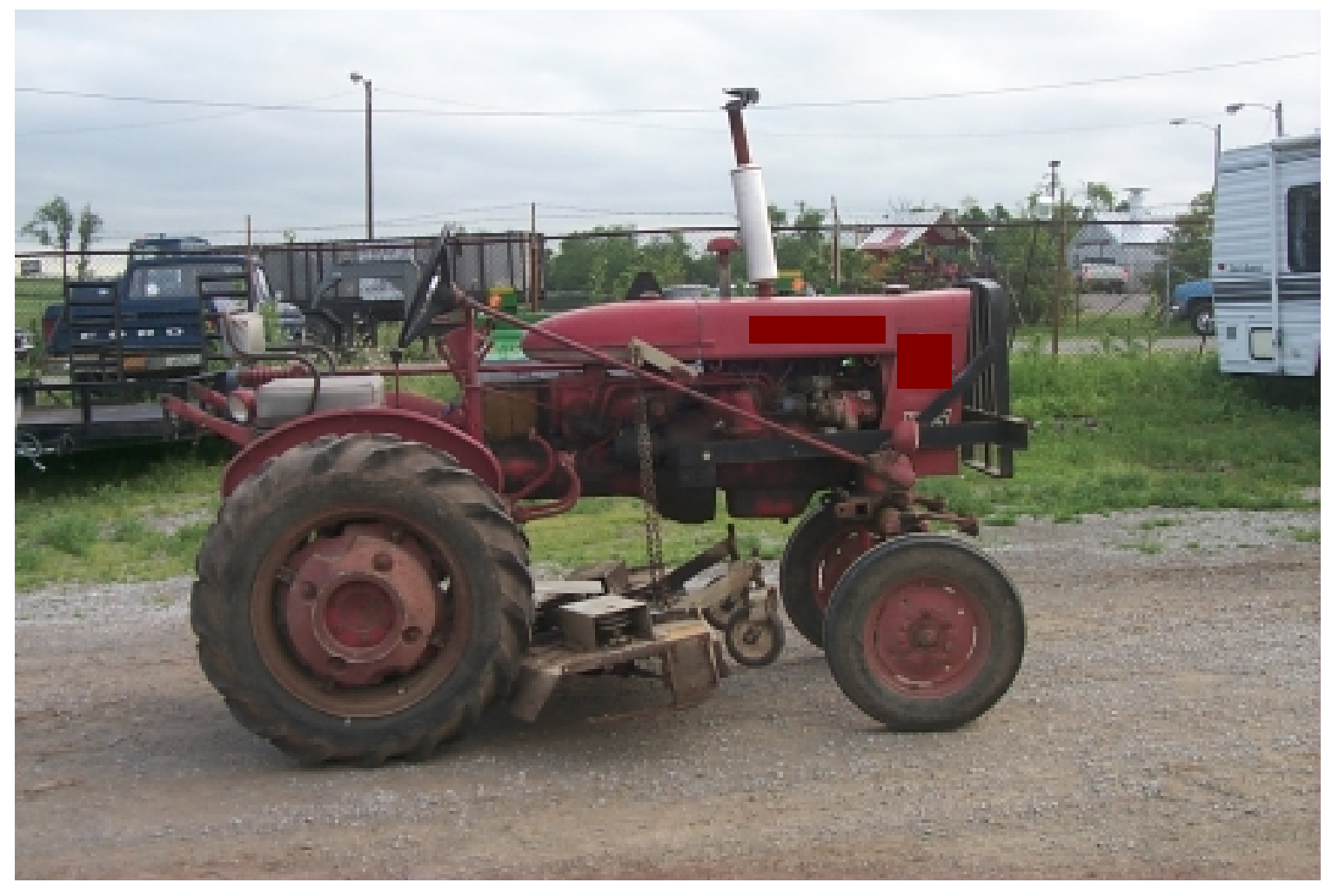

\section{Date of Incident: $\quad$ May 31, 2002 \\ Report Release Date: June 3, 2003 \\ Incident Number: $\quad$ 02KY099}

Kentucky Fatality Assessment and Control Evaluation Progran Kentucky Injury Prevention and Research Center 333 Waller Avenue

Suite 202

Lexington, Kentucky 40504

Phone: 859-323-2981

Fax: 859-257-3909

www.kiprc.uky.edu

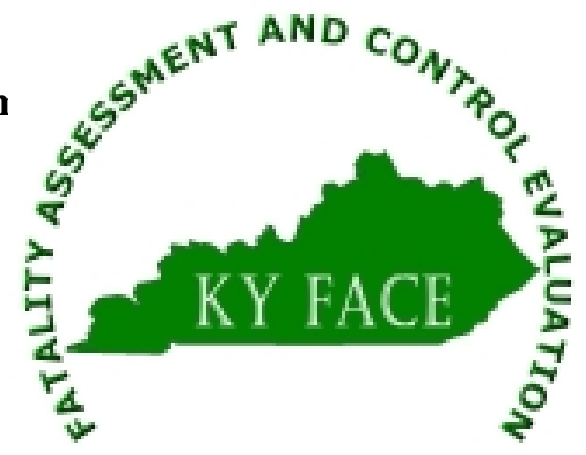


Kentucky Fatality Assessment and Control Evaluation (FACE) Program

Incident Number: 02KY099

Release Date: June 2, 2003

Subject: Hispanic Worker Dies In Tractor Rollover Incident

\section{Summary}

On May 31, 2002, a 25 year-old Hispanic worker (decedent) died when the gasoline-powered tractor he was operating overturned. The incident occurred when the decedent mowed a steep embankment along a rural roadside which caused the tractor to flip over a 3-strand, barbed wire fence, pinning the operator under the seat and tire. A passing motorist noticed the overturned tractor and notified 911, emergency services. Local police and fire departments arrived at the scene, as did a local ambulance. The coroner arrived and declared the tractor operator dead due to asphyxiation and crushing injuries to the chest.

- Tractors should be equipped with rollover protective structures and seatbelts.

- Foreign farm laborers should be trained in their native language on safe operation of farm machinery and informed of dangers of local terrain.

\section{Background}

On November 5, 2002, the Kentucky FACE program was notified of a Hispanic worker who had died on May 31, 2002, when the tractor he was operating overturned. A Kentucky FACE investigator, accompanied by a NIOSH investigator, made a site visit on November 26, 2002. The coroner and two farmers were interviewed. An accident reconstructionist who was at the scene was interviewed on a later date.

The farm the decedent worked on was run by two farmers, Farmer 1 and Farmer 2. Together they farmed approximately 550 acres with Farmer 1 growing tobacco and Farmer 2 raising cattle. In February 2002, the decedent, who had lived in the community since May 2000, approached the farmers for a full-time job. The decedent was hired to work primarily for Farmer 1. When time permitted and when Farmer 2 needed additional help, the decedent worked for him as well. The decedent understood English and communicated with the farmers in broken English. While employed by the farmers, the decedent had safely operated several different tractors and had safely performed assigned farm maintenance tasks. It is unknown if safety training was provided.

\section{Investigation}

On May 31, 2002, a 25 year-old Hispanic male reported for work on the farm where he had been employed since February 2002.

On the morning of the incident, the decedent painted a shed on the farm. As was his usual practice, the decedent went home for lunch. After lunch, the decedent called a friend to say he was on his way to a nearby community to jump-start his car that he previously had to leave there.

The decedent's job upon returning to the farm was to transfer round bales of hay from the hay field to their storage location. After moving the hay bales, the decedent decided to mow the 
roadway. Earlier in the day, he had been instructed by Farmer 1 not to mow a particular banked section of roadway. This section of roadway was either left untrimmed or trimmed with a weedeater. He chose to mow the roadway with an early model tractor with air-filled tires. This particular tractor offsets the driver to the right of the engine block.

At the time of the incident, the tractor operator was mowing in a southwest direction. He had successfully mowed 30 feet beyond a culvert and was on the upper side of an 11.5 foot high bank with a slope of 25 degrees. At the bottom of the bank was a 3 strand, barbed-wire fence supported by iron fence posts. At some point the tractor flipped, rolled down the bank and over the fence, pinning the driver underneath the right wheel and seat of the tractor.

At approximately 6:02 PM on the day of the incident, a passing motorist called 911 emergency medical services and reported a tractor was flipped over and in the ditch of a narrow, rolling, two lane county road which runs northwest and southwest. An ambulance arrived at 6:08 PM. Other responders were the fire department, coroner, and police officer. The police told Farmer 2, who told Farmer 1. There were no eye witnesses to the incident, and an accident reconstructionist was called to the scene.

The accident reconstructionist was also interviewed for this report. He verified the above description of the events of the incident.

\section{Cause of Death}

The local coroner listed the cause of death as due to asphyxiation and crushing injuries to the chest.

\section{Recommendations with Discussions}

Recommendation No. 1: Tractors should be equipped with rollover protective structures and seatbelts.

The tractor involved in this incident was a 1950 tractor. Roll Over Protective Structures were not available for purchase at the time this tractor was manufactured, nor is a commercially made ROPS currently available. However, tractor owners can contact local tractor dealers for ROPS to be retrofitted for older tractors.

Recommendation No. 2: Foreign farm laborers should be trained in their native language on safe practices of operating farm machinery and dangers of local terrain.

Local ethnic leaders and local community groups, such as churches or organizations, could consider organizing training courses for non-English speaking persons pertinent to the type of work required for that local area. These courses should include basic safety training on behavior, machinery and work area and environmental hazards awareness and evaluation. When a language barrier exists, workers should be trained in their primary language and employers should ensure they understand the training received. Training on safe operating procedures of any machinery to be operated by workers should also be provided. 


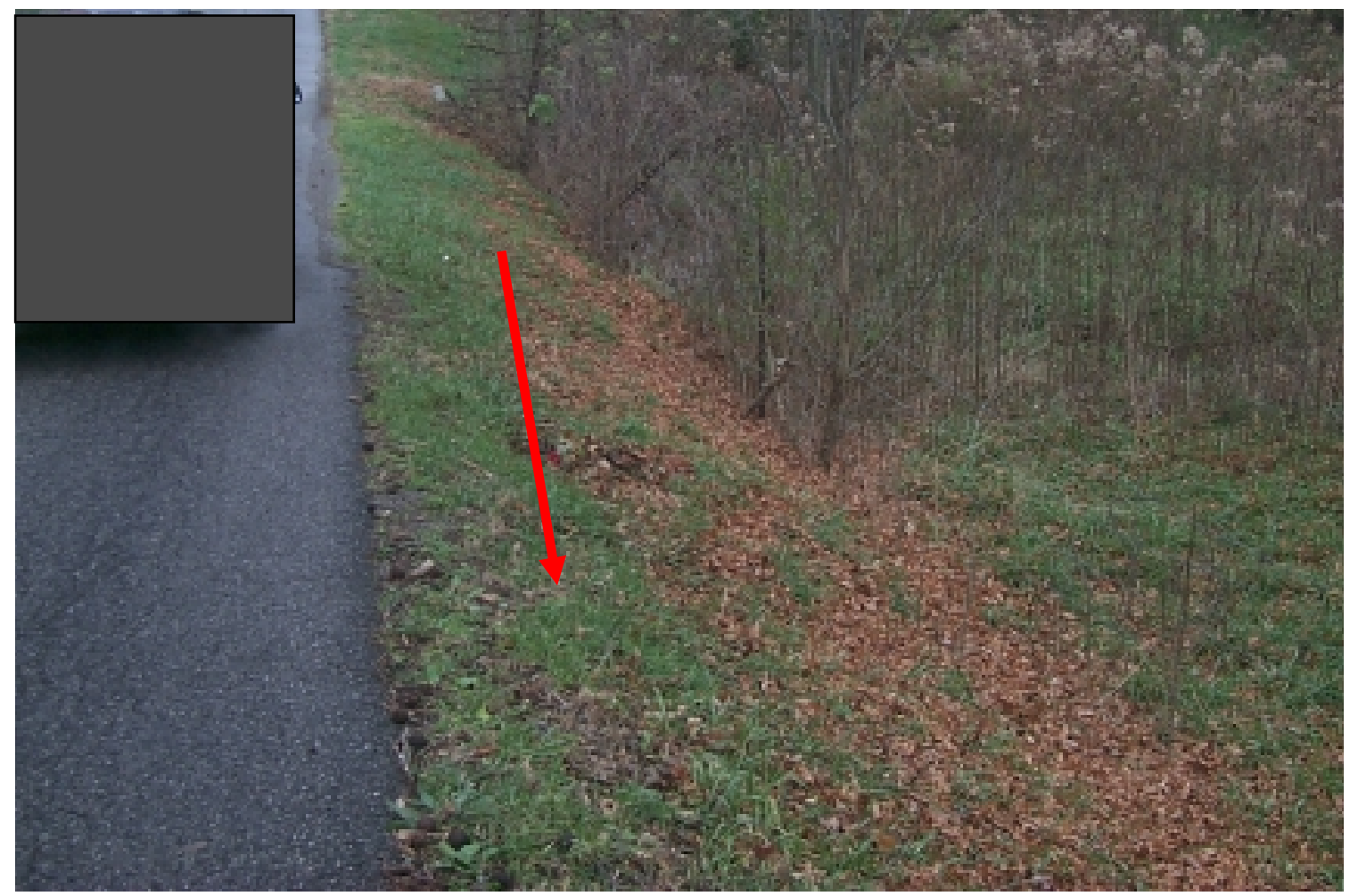

Embankment where tractor rolled. Slope 25 degrees. Arrow denotes direction tractor was moving.

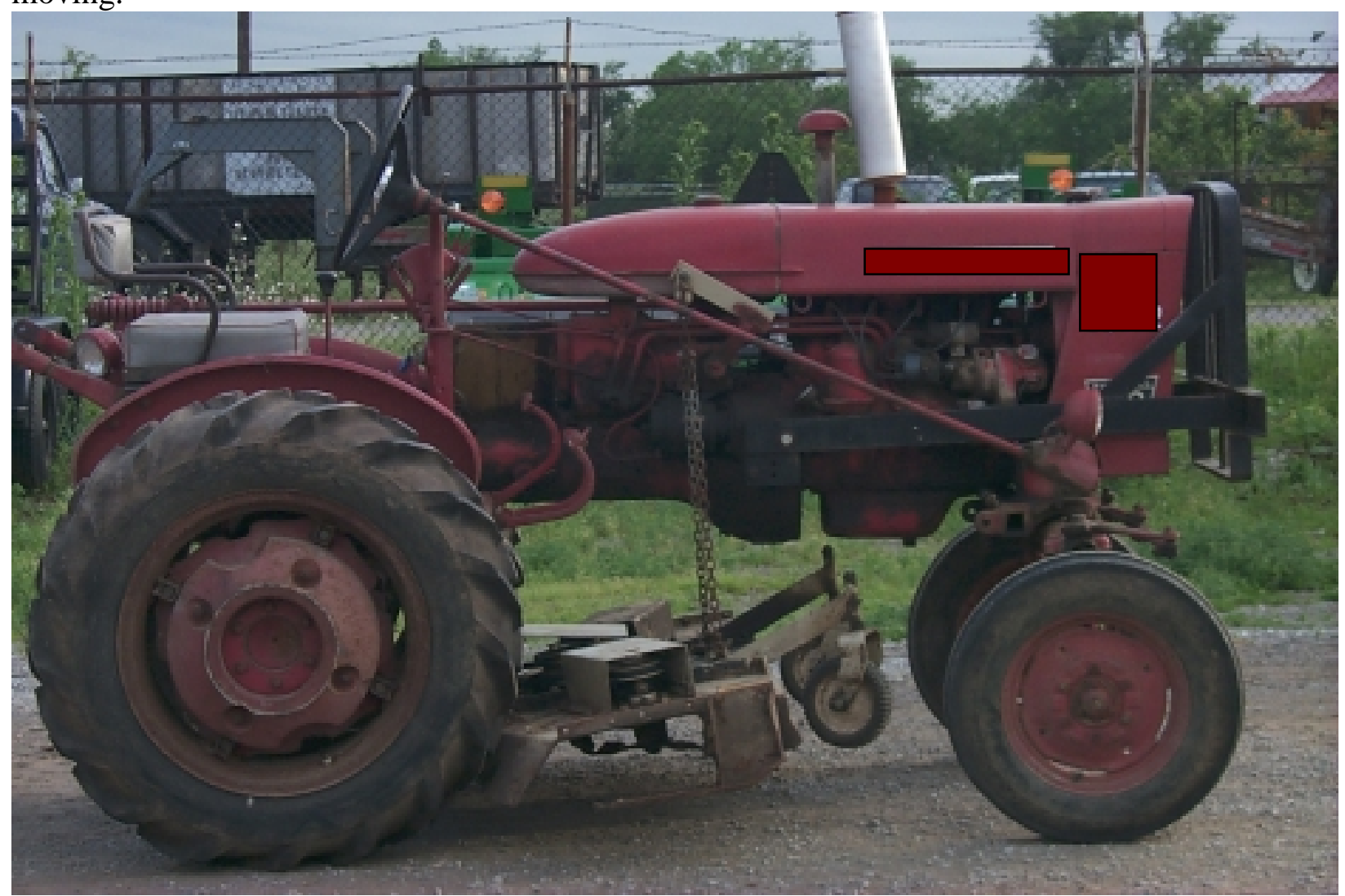

Picture of similar tractor involved in incident. 